\title{
PERAN ORANG TUA TERHADAP PENDIDIKAN ANAK DALAM PERSPEKTIF ISLAM
}

\author{
Nur Laela \\ Dosen Fakultas Kedokteran dan Ilmu Kesehatan \\ Universitas Jendral Soedirman (UNSOED) Purwokerto \\ e-mail:nurlaeladiryat@gmail.co.id
}

\begin{abstract}
Abstrak
Berbicara tentang hadhânah tidak hanya pada hak asuh anak belaka, menlainkan juga mendidik anak, dengan memberikan ta'lìm hingga inkâh (menikahkan) ketika sudah dewasa, lalu terputuskan kewajiban orang tua ketika sang anak sudan menikah. Pembahasan tulisan ini, lebih dispesifikasikan pada pembahasan pendidikan anak (tarbiyatu al-aulâd) dalam kerangka hadhanah perspektif pendidikan Islam, sehingga pada pembahasannya lebih pada bagaimana peran orang tua (role of parents) terhadap masa depan pendidikan anak, baik dalam bidang pendidikan formal maupun non formal sesuai dengan anjuran yang terdapat dalam Islam. Termasuk pembahasan secara implementatif maqashid al-syariah pada konsep hadhanah yang lebih filosofis dan kontekstual.
\end{abstract}

Kata Kunci: pendidikan anak, hadhanah, maqashid al-syariah, pendidikan anak,pendidikan Islam

\section{A. Pendidikan Anak dan Hadhanah}

Dalam pendidikan nanak tidak lepas dari peran orang tua, karena anak juga berhak mendapatkan pendidikan dari orang tua selain hak asuh (hadhanah). Jika merinci hak-hak anak (huqûq li al-aulâd) yang diperolehnya dari orang tua atau otoritas lain yang menggantikan orang tua, maka kita akan dapati bahwa hak-hak tersebut merupakan penjabaran dari dharûriyyât 
al-khamsah tadi. Misalnya hak anak untuk mendapatkan nama dan keturunan nasab, maka itu ada dalam pemeliharaan atas nasab dan kehormatan ( $h i f d z$ an-nasl/hifdzul 'ird), hak untuk mendapatkan pendidikan yang layak, dapat dimasukkan ke dalam pemeliharaan atas agama (mendapatkan pendidikan agama dan akhlâqul karîmah), dan pemeliharaan atas akal (hifz al-'aql) yang juga berarti mencerdaskan anak melalui pendidikan, dan seterusnya. ${ }^{1}$

Tentang hadhânah (pendidikan anak) ini, Islam sendiri merinci sedemikian rupa hingga ke masalah perkembangan yang optimal bagi jiwa anak yang termasuk kategori hifz an-nafs. Misalnya ketika membicarakan masalah hadhânah (menyangkut anak di bawah usia tiga tahun) dan radhâăh (proses menyusui) anak diutamakan untuk berada dalam perawatan ibunya, jika ibu tidak ada atau berhalangan, tetap kedudukannya digantikan orangorang yang terdekat kepada ibunya, yaitu saudara-saudara perempuan dari ibunya, begitu seterusnya. Meskipun secara equality (kesetaraan), peranan hadhânah (perawatan, perlindungan [child care], dan juga pendidikan anak [socialization] sebenarnya menjadi peran bersama dalam status kehidupan keluarga (peran orang tua dalam keluarga) baik suami maupun isteri. ${ }^{2}$

Dalam ilmu psikologi anak, bahwa usia di bawah tiga tahun adalah masa pembentukan kepribadian yang amat menentukan yang jika terganggu akan menyebabkan anak berpotensi menjadi anak bermasalah di masa depan dan itu tergantung pada peran orang tua (role of parents) dalam menjalankan hak dan kewajibannya terhadap pendidikan anak (child socialization) dan perlindungan anak (child care). Terutama dalam mencapai pendidikan anak menuju imtaq dan iptek. ${ }^{3}$ Oleh karena itu, nilai-nilai ini sangat penting bagi pengembangan pendidikan anak oleh orang tua, terutama peran seorang ibu yang begitu dominan, karena faktor kedekatan emosional, termasuk peran seorang bapak yang mempunyai hak dan kewajiban yang sama dalam hal melindungi, mengasuh, memelihara, dan mendidik anak, sehingga akan tercapai apa yang menjadi tujuan agama yang mencakup dalam maqâshid

\footnotetext{
1 Amir Mua'allim dan Yusdani, Konfigurasi Pemikiran Hukum Islam, (Yogyakarta: UII Press, 1999), hlm. 42.

2 F. Ivan Nye et.all; Role Structure and Analysis of the Family, Published in Coopration With The National Council On Family Relations, (London: Sage Library of Social Research, 1976), hlm. 33-35.

3 Ahmad D. Marimba, Pengantar Filsafat Pendidikan Islam, (Bandung: A-Ma'arif, 1989), hlm. 19.
} 
asy-syarîah yang merupakan tujuan ajaran agama yang komprehensif untuk mencapai kesejahteraan keluarga (terutama dalam perkembangan anak) baik dalam bidang ekonomi, sosial, politik, dan kesejahteraan pendidikan yang menjadi tujuan universal bagi para orang tua.

Dari maqâshid asy-syarîah atau menemukan nilai-nilai syari'ah (syariah values $)^{4}$ inilah penulis ingin menelusuri nilai-nilai filosofis hukum keluarga dari aspek hadhânah pada umumnya, dan pendidikan anak pada khususnya. Nilai-nilai ini sangat identik dengan hikmah, faedah, fungsi, dan substansi dari nilai-nilai hadhânah dalam hukum keluarga Islam. Sedangkan hikmah (faedah) dari hadhânah (pendidikan anak) tersebut sangat besar dan berimplikasi terhadap perkembangan masa depan dan kecerdasan anak. Menelusuri nilai-nilai filosofis hukum keluarga Islam tentang hadhânah yang spesifikasinya pada penekanan pendidikan anak merupakan sesuatu yang langka dilakukan, sehingga para orang tua tidak mengerti arti dari diwajibkannya hadhânah yang mempunyai makna yang sangat dalam (deep meaning), mengandung asrâr al-ahkâm (rahasia-rahasia hukum Islam) yang perlu disingkap untuk diimplementasikan dalam ranah hukum keluarga Islam yang sangat kaya nilai dan hikmah (faedah) yang sangat besar. ${ }^{5}$ Dari sinilah tulisan ini menjadi penting sebagai kontribusi pengetahuan (contribution to knowledge) khususnya dalam bidang filsafat hukum keluarga Islam tentang hadhânah (pengasuhan, pemeliharaan, dan pendidikan anak) mulai usia dini hingga dewasa.

\section{B. Nilai Filosofi Islam tentang Hadhanah dalam Pendidikan Anak}

Hadhânah berasal dari kata Hidban, yang berarti lambung. Seperti kalimat hadbana ath-thâiru baidhabu, "burung itu mengepit telur dibawah sayapnya," begitu juga dengan perempuan (Ibu) yang mengasuh anaknya. Hadhânah menurut bahasa berarti "meletakkan sesuatu dekat tulang rusuk

4 Yudian Wahyudi, Maqashid Syari'ah dalam Pergulatan Politik Berfilsafat Hukum Islam dari Harvard ke Sunan Kalijaga, (Yogyakarta: Nawesea Press, 2007), hlm. 8-9., A. Qodri Azizi, Eklektisisme Hukum Nasional: Kompetisi Antara Hukum Islam dan Hukum Umum, (Yogyakarta: Gama Media, 2002), hlm. 55-57., dan Imam Syaukani, Rekonstruksi Epistemologi Hukum Islam Indonesia dan Relevansinya Bagi Pengembangan Hukum Nasional, (Yogyakarta: Rajawali Press, 2006), hlm. 172-176.

5 Fathurrahman Djamil, Filsafat Hukum Islam, (Jakarta: Logos Wacana Ilmu, Cet. Ke-3, 1999), hlm. $1-2$. 
atau di pangkuan”, karena ibu waktu menyusui anaknya meletakkan anak itu dipangkuannya, seakan-akan ibu di saat itu melindungi dan memelihara anaknya, sehingga hadhânah dijadikan istilah yang maksudnya pendidikan dan pemeliharaan anak sejak lahir hingga sanggup berdiri sendiri mengurus dirinya yang dilakukan oleh kerabat anak itu. Dalam arti lain hadhânah merupakan pemeliharaan anak laki-laki atau perempuan yang masih kecil, serta mendidiknya hingga dewasa. ${ }^{6}$ Pembahasan ini lebih ditekankan pada pendidikan anak (chiled care). Meskipun hadhânah secara umum mencakup perlindungan, pemeliharaan, hak pengasuhan, hak menyusui terhadapa anak bagi ibu dan seterusnya. Di sini, pendidikan anak adalah peran dan kewajiban orang tua hingga ia dewasa.

Seorang anak pada permulaan hidupnya sampai umur tertentu memerlukan orang lain dalam kehidupannya, baik dalam pengaturan fisiknya, maupun dalam pembentukan akhlak (moral) dan pendidikannya. Seseorang yang melakukan tugas hadhânah sangat berperan dalam hal tersebut. Oleh karena itu, masalah hadhânah mendapat perhatian khusus dalam hukum keluarga Islam. Apabila kedua orangtuanya tidak dapat atau tidak layak untuk menjalankan tugas itu disebabkan tidak mencukupi syarat-syarat yang diperlukan menurut pandangan Islam, maka hendaklah dicarikan pengasuhan anak yang mencukupi syarat-syaratnya. Untuk kepentingan seorang anak, sikap peduli dari kedua orangtua terhadap masalah hadhânah memang sangat diperlukan. Jika tidak, maka bisa mengakibatkan seorang anak tumbuh tidak terpelihara dan tidak terarah seperti yang diharapkan. Dalam hal ini, seorang ayah diwajibkan membayar upah kepada pembantu (pemelihara/pendidik orang lain). ${ }^{7}$

Akan tetapi, yang paling diharapkan adalah keterpaduan kerjasama antara ayah dan ibu dalam melakukan tugas hadhânah (pendidikan anak) ini. Jalinan kerjasama antara keduanya hanya akan bisa diwujudkan selama kedua orang tua itu masih tetap dalam hubungan suami-isteri. Dalam suasana demikian, kendatipun tugas hadhânah sesuai dengan tabiatnya akan lebih banyak dilakukan oleh pihak ibu, namun peranan ayah tidak bisa diabaikan,

6 HLM.S.A. Hamdani, Risalah Nikah, (Hukum Perkawinan Islam), terj. Agus Salim, (Jakarta: Pustaka Amani, 2002), hlm. 318.

Ibid., hlm. 322 . 
baik dalam memenuhi semua kebutuhan yang memperlancar tugas hadhânah, maupun dalam menciptakan suasana damai dalam rumah tangga dimana anak diasuh dan dibesarkan oleh orang tua. Tugas ini tidak akan terasa berat kalau pihak yang berkewajiban (ibu dan ayah) benar-benar merasakan faedah (bikmah) dari hadhânah (pemeliharaan dan pendidikan anak) ini demi masa depan anak dan kelak orang tua yang akan merasakan hasil dan manfaatnya ketika si anak sudah dewasa.

Pendidikan sendiri secara etimologis mempunyai empat arti; Pertama, pertambahan, perkembangan, dan pemberian makanan yang bergizi; Kedua, pertumbuhan dan perkembangan; Ketiga, perbaikan dan penanganan; Keempat, pemeliharaan anak dengan memberikan makanan yang bergizi dan pengasuhan (pendidikan) dengan sebaik-baiknya sampai akhir masa kanakkanaknya. ${ }^{8}$ Bahkan pendidikan dimulai sejak dalam kandungan oleh ibunya, hingga ia melahirkan. Kata pendidikan (education) berarti pengarahan atau pembentukan pola hidup, adaptasi dengan alam sekitarnya, peradaban, penentuan kehidupan, transfer informasi dan kecakapan, pembentukan motivasi internal untuk menghadapi tantangan eksternal, perkembangan di setiap hal yang ada di masyarakat dan kehidupan, pemurnian tradisi dan peninggalan, penemuan bakat dan persiapan diri anak dengan baik. Secara terminologi, pendidikan anak (child education) berarti proses pembangunan kejiwaan anak secara perlahan sampai batas kesempurnaan manusia. ${ }^{9}$

Nilai filosofis (hikmah) dari hadhânah (pendidikan anak) dalam Islam ini dapat ditelusri melalui ayat-ayat al-Qur'an, hadits-hadits Nabi, dalam kajiankajian fiqh seperti yang ditulis oleh Ali Ahmad al-Jarjani dalam kitabnya yang berjudul Hikmatu at-Tasyrî Wa Falsafatuhû, ia cukup komprehensif menulis tentang hikmah/nilai/faedah (value) dalam hukum keluarga seperti hikmah nikah, hikmah poligami, mawaris, iddah, rujuk, hingga hadhânah yang mencakup hak untuk mendapatkan perlindungan, pemeliharaan, dan pendidikan. Kesemuanya merupakan cakupan dari apa disebut disebagai hikmah wa falsafatu at-tasyrî' (hikmah dan nilai-nilai sebuah syari'ah/hukum Islam) seperti yang disebut di atas. ${ }^{10}$

\footnotetext{
8 Hidayatullah Ahmad, Ensiklopedi Pendidikan Anak Muslim, terj. Sari Narulita dan Umron Jayadi, (Jakarta: Fikr Rabbani Grop, 2006), hlm. 18.

Ibid.

10 Ali Ahmad al-jarjani, Hikmatu at-Tasyrı" Wa Falsafatubûu, (Libanon: Dâr al-Fikr, t.t.), hlm. 7-15.
} 
Dalam al-Qur'an, kata hikmah yang berarti filsafat sebagai ilmu hikmah disebut sebanyak 20 ayat bahkan Nabi Muhammad mampu menangkap dimensi yang immaterial yang diperolehnya melalui akal dan oleh Ibnu Sina disebut sebagai al-hads yang mempunyai kekuatan suci. ${ }^{11}$ Tentunya sesuatu yang immaterial ditangkap oleh Nabi Muhammad merupakan hasil penyingkapan sebuah makna, nilai, maksud, tujuan, dan seterusnya, sehingga tertuang dalam sebuah rumusan yang dikenal dengan hukum Islam. Dalam hal ini adalah nilai-nilai perintah dari hadhânah (pengasuhan dan pendidikan anak) mempunyai hikmah (faedah) tersendiri sebagaimana yang sudah terekam

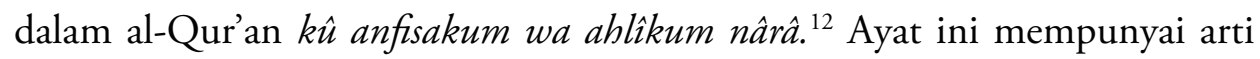
yang sangat dalam untuk pendidikan keluarga dan anak. Artinya memelihara anak adalah kewajiban bersama, ibu dan ayah, karena anak memerlukan pemeliharaan, dan asuhan, juga harus dipenuhi kebutuhannya serta harus diawasi (diarahkan) pendidikannya. ${ }^{13}$

Secara umum, pendidik adalah orang yang memiliki tanggungjawab untuk mendidik. Apabila dililihat secara khusus, pendidik dalam perspektif pendidikan Islam adalah orang-orang yang bertanggungjawab terhadap perkembangan peserta didik dengan mengupayakan perkembangan seluruh potensi peseta didik, baik potensi afektif, kognitif, maupun psikomotorik sesuai dengan nilai-nilai ajaran Islam. Menurut Suryosubrata, pendidik adalah orang dewasa yang bertanggungjawab memberi pertolongan pada anak didik dalam perkembangan jasmani dan rohaninya, agar mencapai tingkat kedewasaan, mampu berdiri sendiri dan memenuhi tingkat kedewasaannya, mampu berdiri sendiri memenuhi tugasnya sebagai hamba dan khalifah Allah Swt. di bumi, dan mampu sebagai makhluk soial, dan sebagai makhluk individu yang mandiri. ${ }^{14}$

Menurut Imam Al-Ghazzali, pendidik adalah orang yang berusaha membimbing, meningkatkan, menyempurnakan, dan mensucikan hati

\footnotetext{
11 Musa Asy'arie, "Filsafat Islam Suatu Tinjauan Ontologis", dalam Amin Abdullah dkk., Irma Fatimah (ed)., Filsafat Islam kajian Ontologis, Epistemologis, Aksiologis, Historis, dan Perspektif, (Yogyakarta: LESFI, 1992), hlm. 13-14.

12 Mengenai ayat-ayat pendidikan dan keluarga, dapat dilihat dalam Q.S. Luqman: 12-19.

13 HLM.S.A. Hamdani, Risalah Nikah, (Hukum Perkawinan Islam), terj. Agus Salim, (Jakarta: Pustaka Amani, 2002), hlm. 318.

14 Suryosubrata B., Beberapa Aspek Dasar Kependidikan, (Jakarta: Bina Aksara, 1983), hlm. 26
} 
sehingga menjadi dekat dengan Khaliknya. ${ }^{15}$ Sifat-sifat yang harus dimiliki pendidik sebagaimana tercantum dalam al-Qur-an, diantaranya: sifat shiddiq, sebagaimana dalam surat an-Nisa:104, amanah sebagaimana surat al-Qashash:26, Tabligh, Fathanah, Mukhlish sebagaimana surat al-Bayyinah:5, Sabar sebagaimana surat al-Muzammil:10, dan surat Ali Imron:159, Saleh (mencintai, membina, menyokong kebaikan) sebagaimana surat an-Nur:55, Adil sebagaimana surat al-Maidah:8, mampu mengendalikan diri sesuai diri sendiri sebagaimana surat an-Nur:30, kemampuan kemasyarakatan sesuai surat Ali Imron:112, dan ketaqwaan kepada Allah sebagimana surat al-A'raf:26, dan surat al-Mudatstsir: $1-7) .{ }^{16}$

Menurut Imam Al-Ghazali, pendidik dituntut memiliki beberapa sifat keutamaan yang menjadi kepribadiannya, diantanya sabar, kasih sayang, sopan, tidak riya', tidak takabbur, tawadhu', pembicaraan terarah, bersahabat, tidak pemarah, membimbing dan mendidik dengan baik, sportif, ikhlas dan lainnya, sehingga al-Ghazzali berpendapat bahwa pendidik tidak boleh meminta bayaran dan apabila bila mengajar ilmu agama hanya boleh menerimanya. ${ }^{17}$ Meskipun pendapat Imam al-Ghazzali ini masih perlu diinterpretasikan dalam masalah gaji. Artinya, penekakan al-Ghazzali lebih pada unsur keikhlasan bagi para pendidik terutama orang tua yang mendidik anak setidaknya berangkat dari ketulusan hati dan keikhlasan orang tua dalam mendidik anak, tanpa harus ada embel-embel, semata-mata tanggungjawab orang tua terhadap anak. Begitu juga dengan pendidik (teacher) dalam konteks pendapat al-Ghazzali di atas harus dengan penuh ikhlas dan tanggugjawab terhadap peserta didik, karena semata-mata amanah untuk mendidik anak.

Sedangkan menurut Ibnu Khaldun bahwa pendidik harus memiliki metode yang baik dan mengetahui faedah yang dipergunakannya. Disamping itu Ibnu Khaldun menganjurkan agar pendidik bersikap sopan dan halus pada muridnya. Hal ini termasuk juga sikap orang tua terhadap anaknya, karena orang tua adalah pendidik utama. Selanjutnya jika keadaan memaksa harus memukul si anak, maka pukulan tersebut tidak boleh lebih dari tiga kali.

\footnotetext{
15 Imam al-Ghazzali, Ihyâ' 'Ulûmuddîn, (Beirut: Dar al-Fikr, 1939), hlm. 13

16 Ibid.

17 Ibid.
} 
Sedangkan pendidik boleh menerima ujrah (upah) dari hasil mengajarnya. ${ }^{18}$ Pendapat al-Ghazzali dan Ibnu Khaldun ini sebenarnya hampir sama, yaitu berorientasi pada keikhlasan mendidik, tanggungjawab, tidak otoriter terhadap peserta didik, komunikatif, dan tidak boleh ada kekerasan terhadap peserta didik. Menurut hemat penulis, nilai-nilai inilah sebenarnya yang ingin dikemukakan al-Ghazzali dan Ibnu Khaldun yang mempunyai relevansi dan implementasi bagi perkembangan dunia pendidikan saat ini.

Ikhwan ash-Safa juga berpendapat tentang pendidik yang baik dan ideal yaitu sifat-sifat yang harus dimiliki oleh pendidik (guru, dosen, dan orang tua terhadap anak) adalah harus mempunyai kecerdasan (intelectual question), baik akhlaknya, lurus tabi'atnya, bersih hatinya, menyukai ilmu, bertugas mencari kebenaran, dan tidak bersifat fanatisme terhadap suatu aliran. Menurut hemat penulis walaupun dalam hal ini Ikhwan ash-Safa tidak konsisten karena pendidik versi mereka harus sesuai denan organisasi dan tujuannya. Mereka memiliki aturan tentang jenjang pendidik yang dikenal dengan nama ashhâb an-Namûs. Mereka itu adalah Múallim, Ustâdz dan mu'addib. kata Mu'allim yang juga berarti guru (teacher), pelatih (instructor), dan pemandu (trainer). Selanjutnya kata Mu'addib berarti pendidik (educator) atau teacher in Koranic School (guru dalam lembaga pendidikan Al-Qur-an). ${ }^{19}$ Guru jiwa universal adalah akal aktual; dan akhirnya Allah-lah sebagai guru dari segala sesuatu yang terangkum dalam al-Qur'an. ${ }^{20}$

Dalam konteks Indonesia, pendapat Ikhwan ash-Safa ini perlu direvitalisasi dan reinterpretasi mengenai pendapatnya yang mengatakan bahwa dalam pendidikan tidak boleh menganut mazdhab-madzhab, fanatisme aliran, ideologisasi dan seterusnya. Menurut hemat penulis memang pendapat Ikhwan ash-Safa ini mempunyai tujuan yang baik. Artinya, fanatisme faham dapat mempengaruhi pada perkembangan pendidikan dan keilmuan seorang peserta didik. Melihat kemajemukan di Indonesia ini seorang pendidik harus objektif dan komprehensif dalam memberikan ilmu pengetahuan bagi

\footnotetext{
18 Muhammad Munir Mursi, At-Tarbiyah Al-Islâmiyyab: Ushûlubâ Tathawnurubâ fî al-Bilâd al-Arabiyah, (Mesir, Dar Al-Ma'arif, 1987), hlm. 255.

19 Hans Wehr, A Dictionay of Modern Written Arabic, (Beirut: Librairie du Liban, Cet. Ke-4, 1974), hlm. 15.

20 Ahmad Fu'ad Al-Ahwani, At-Tarbiyah fí al-Islâm, (Mesir: Dar al-Ma’arif, t.t.), hlm. 248
} 
peserta didik. Artinya, tidak boleh ada unsur-unsur ideologisasi. Kalau sebatas pengenalan pengetahuan tidak menjadi masalah, sehingga peserta didik diberi kebebasan dalam berfikir dan bahkan dalam menganut agama sekalipun. Akan tetapi, peran orang tua dan pendidik (guru, doses, ustadz, atau lembaga) sangat menentukan bagi perkembangan peserta didik, sehingga syarat-syarat objektif, selektif, dan komprehensifness dalam keilmuan harus dimiliki oleh para pendidik (teachers).

Sifat-sifat pendidik (guru, dosen, ustadz, atau lembaga) diatas, sebenarnya peran yang dibebankan orang tua untuk mendidik anaknya, tetapi andaikata orang tua memberikan mandat anaknya kepada orang lain (dalam hal ini guru atau lembaga) juga berlaku seperti halnya peberian upah (ujrah) kepada orang lain dalam mengasuh anak. ${ }^{21}$ Dalam hal hadhânah (khususnya dalam mendidik anak) adalah menjadi kewajiban kedua orang tua. Peran orang tua (role of parents) ini sangat menentukan pada perkembangan kepribadian dan intelekutalitas anak, sehingga orang tua menjadi sentral pendidikan dalam keluarga.

\section{Landasan dalil Al-Qur'an tentang Pendidikan Anak}

Sebagaimana yang kita ketahui bahwa hadhânah sebenarnya bermakna pemeliharaan anak, laki-laki maupun perempuan yang masih kecil, atau anak dungu yang tidak dapat membedakan sesuatu dan belum dapat berdiri sendiri, menjaga kepentingan anak, melidungi dari mendidiknya, jasmani dan rohani, serta akalnya, supaya si anak dapat berkembang mengatasi persoalan hidup yang akan dihadapinya. Dalam konteks pendidikan bahwa pemeliharaan yang terbaik dalam memelihara anak adalah pendidikan di masa kanak-kanak yang berada dalam asuhan orang tua. Berbicara landasan dalil-dalil tentang hadhânah (pendidikan anak) ini sudah sering diungkapkan dalam ayat alQur'an QS. Luqman ayat 12-19. Dalam ayat ini dapat ditelusuri nilai-nilai filosofisnya mengenai pendidikan anak (tarbiyatu al-aulâd) terdapat delapan hal yang sangat penting.

Pertama, mengajarkan untuk bersyukur terhadap nikmat Allah; Kedua, tidak menyekutukan Allah dengan yang lainnya; Ketiga, Berbuat baik

21 HLM.S.A. Hamdani, Risalah Nikablm..., hlm. 321. 
(berbakti) kepada kedua orang tua; Keempat, Mempergauli orang tua secara baik (márûf); Kelima, Menyadarkan bahwa setiap perbuatan sekecil apapun akan mendapatkan balasan dari Allah; Keenam, menaati perintah Allah Swt. seperti shalat, amar máruf dan nahi munkar dan sabar dalam menghadapi cobaan; Ketujuh, tidak sombong dan angkuh; Kedelapan, sederhana dalam bersikap dan bertutur kata. ${ }^{22}$ Dalam ajaran Islam, hadhânah atau pemeliharaan anak dan pendidikannya menjadi kewajiban bagi kedua orang tuanya. Bahkan dalam hal pendidikan seorang ibu dan ayah wajib mengajarkan menulis, memberi nama yang baik, mengajarinya sopan santun (akhlâqul karîmah) dan seterusnya. ${ }^{23}$ Jika semua hal yang sudah disebutkan tersebut dilakukan, maka akan terbentuk keluarga yang sakinah (tenteram), mawaddah (cinta kasih), dan rahmah (penuh kasih sayang) dalam rumah tangga. ${ }^{24}$

Akan tetapi, yang menjadi problem di sini bagaimana pemeliharaan dan pendidikan anak jika terjadi perceraian. Bila terjadi pemutusan perkawinan akibat perceraian, ibu dan ayah tetap mempunyai kewajiban memelihara dan mendidik anak semata-mata untuk kemaslahatan anak. Dalam hal ini masih kontroversial mengenai pengasuhan anak pasca perceraian, tetapi kalau merujuk pada hadits Nabi, ibu lebih berhak terhadap pengasuhan anak, karena terkait dengan menyusui (radâah) dan seterusnya. ${ }^{25}$ Seperti dalam hadits Nabi yang diriwayatkan oleh Ahmad dan Abu Dawud bahwa seorang perempuan mengadu kepada Rasulullah yaitu, "Ya Rasulullah, perutku adalah kantongku, pengakuanku adalah tempat duduknya dan susuku adalah tempat minumnya. Kemudian ayahnya akan memisahkan dariku," Maka Rasulullah Bersabda "Engkau lebih berhak mengasuh anak selama engkau belum menikah dengan laki-laki lain”. ${ }^{26}$ Menurut pernyataan Abu Bakar Ash-Shiddiq bahwa ibu lebih cenderung (sabar) kepada anak, lebih halus, lebih pemurah, lebih penyantun, lebih baik dan penyayang, dan bahkan ia lebih berhak atas anaknya. ${ }^{27}$

\footnotetext{
Amiur Nuruddin dan Azhari Akmal Tarigan, Hukum Perdata..., hlm. 294-295.

Ibid.

Ibid.

Ibid.

Ibid., hlm. 296.

Ibid., hlm. 297.
} 


\section{Peran Orang Tua terhadap Hak Mendidik Anak dalam Kaca Mata Islam}

Mengacu pada pendapat Imam al-Ghazzali bahwa peran orang tua terhadap pendidikan anak sangat dominan. Dalam ushul fiqh dikenal dengan istilah hifd an-Nafs di sini dapat menjadi perkembangan psikis atau psikologi anak yang lebih sehat dan peka terhadap sosial, hifd al-'Aql juga dapat meningkatkan kapasitas intelektual anak dengan cara mendidik, berfikir positif, kritis, cerdas, dan produktif, hifd an-Nash dapat menjaga martabat keluarga dan menjaga nama baik keluarga, dan hifd al-Mâl di sini juga berfungsi bagi bekal kehidupan anak termasuk bekal dalam memperoleh pedidikan yang layak, hak dan memperoleh hartas warisan bagi anak bagi orang tua sangat penting untuk dipikirkan demi masa depan anak. Dharûriyât al-khamsah tersebut di atas adalah menjadi pilar bagi perlindugan anak yang sangat penting bahkan menjadi penunjang bagi kehidupan anak ke depannya hingga dewasa.

Dalam Al-Qur'an juga telah dijelaskan kedudukan orang tua sebagai pendidik anak-anaknya, sebagaimana Allah berfirman dalam surat Luqman: Dan (ingatlah) ketika Luqman berkata kepada anaknya, diwaktu ia memberi pelajaran kepadanya "Hai anakku janganlah kamu mempersekutukan Allah, sesungguhnya mempersekutukan (Allah) adalah benar-benar kedzaliman yang besar. ${ }^{28}$ Al-Qur'an menyebutkan sifat-sifat yag harus dimiliki orang tua sebagai guru yaitu pertama dan utama adalah ketuhanan dan pengenalan Tuhan yang pada akhirnya akan memiliki hikmah (faedah) atau kesadaran tentang kebenaran yang diperoleh melalui ilmu dan rasio. dapat bersyukur kepada Allah, suka menasehati anaknya agar tidak mensekutukan Tuhan, memerintahkan anaknya agar melaksanakan shalat, sabar dalam menghadapi penderitaan.

Kedudukan orang tua sangat penting dalam membina dan mendidik anak-anaknya, karena orang tua yang paling bertanggung jawab terhadap anak keturunannya. Masa depan dan keyakinan anak (baik dalam aqidah maupun agama) tergantung dari peran orang tua (role of parents). Sebagaimana yang disabdakan Nabi Muhammad Saw. Yaitu Tiap-tiap anak terlahir dalam keadaan

28 Lihat juga dalam Q.S. Luqman: 12-19. 
fitrah (suci), maka kedua orang tuanyalah yang menjadikannya seorang Yahudi, Nasrani, Majusi. (HR. Bukhari dan Muslim). Orang tua disamping memiliki kewajiban memberi nafkah kepada anak-anaknya juga berkewajiban untuk membina dan mendidiknya. Dua kewajiban ini tidak bisa dipisahkan, karena menjadi tanggungan orang tua kepada anaknya. Dalam realitanya kebanyakan orang tua tidak kuasa secara langsung untuk mendidik anak-anaknya. Hal ini karena beberapa aspek yang tidak mungkin untuk dilaksanaknnya, baik karena aspek kesempatan, kemampuan dan kendala-kendala lainnya. ${ }^{29}$

Tidak dapat dipungkiri oleh siapapun, bahwa anak adalah generasi penerus, baik bagi orang tua, bangsa maupun agama. Baik buruknya anak, akan menjadi apa mereka, tergantung bagaimana orang tua, bangsa maupun agama mendidik mereka. ${ }^{30}$ Dalam Islam, anak diibaratkan kertas putih, suci sejak lahir, dan oleh karenanya mau beragama apa, menjadi apa dan bagaimana masa depannya, tergantung bagaimana cara kedua orang tua mewarnai mereka. Sudah jelas, landasan dalil, baik dalam al-Qur'an dan hadis yang berbicara soal hadhânah (mendidik anak) merupakan tanggungjawab orang tua. Sebagaimana yang sudah disabdakan Nabi Muhammad yang diriwayatkan oleh at-Turmudzi, Ibnu Majah, Shahih Bukhari dan Muslim mengenai pesoalan tanggungjawab orang tua terhadap pendidikan anak.

Terdapat berbedaan cara dan orientasi bagi pendidikan anak laki-laki dan perempuan. Meskipun secara subtansial sama, tetapi menuntut ilmu (thalab al-ilm) itu wajib bagi muslim laki-laki dan perempuan. Bahkan terdapat penekanan Imam al-Ghazzali untuk pendidikan anak perempuan, karena ia juga memndang perempuan mempunyai potensi yang sama dengan lakilaki, meskipun secara bakat dan minat pasti berbeda. Bahkan al-Ghazzali juga memberikan contoh yang cocok bagi pendidikan perempuan adalah, ilmu kedokteran, pendidikan guru, dan juga ilmu jahit. Ini kemudian yang disebut al-Ghazzali bahwa menuntut ilmu adalah fardlu kifayah dan fardlu 'ain. Ilmu kedokteran dan ilmu jahit bagi perempuan adalah fardlu kifayah, sedangkan menuntut ilmu agama adalah fardlu 'ain baik bagi laki-laki dan perempuan. ${ }^{31}$

29 HLM.S.A. Hamdani, Risalah Nikahlm..., hlm. 318-321.

30 Imam Suprayogo, Pendidikan Berparadigma Al-Qur'an, (Malang: Aditya Media, t.t.), hlm. 12.

31 Munir Muhammad al-Ghadhban, Menyiapkan Anak Perempuan Shalehah Untuk Pemuda Muslimah, Terj. Saiful hadi, (Jakarta: Mustaqim, Cet. Ke-2, 2003), hlm. 16-17. 
Bagi anak laki-laki juga mendapatkan kewajiban yang sama dalam menuntut ilmu, tentunya dengan pengarahan kedua orang tua. Oleh karena itu, peran orang tua, wajib hukumnya untuk mengarahkan pendidikan anak (child carel socialization care). Baik laki-laki maupun perempuan sesuai bakat dan minat masing-masing.

Dalam perspektiffiqh para ulama telah sepakat bahwa hadhânah (mendidik dan merawat anak) hukumnya adalah wajib. Dalam hal ini, terdapat perbedaan pendapat mengenai apakah hadhânah ini mejadi hak orang tua (terutama ibu) atau hak anak. Dalam hal ini misalnya Imam Hanafi dan Maliki berpendapat bahwa hadhânah itu menjadi hak orang tua (terutama ibu), sehingga ia dapat saja menggugurkan haknya. Akan tetapi, jumhur ulama hadhânah menjadi hak bersama (suami, isteri, dan juga anak). Bahkan menurut Wahbah AzZuhaily hak hadhânah adalah hak bersyarikat antara ibu, ayah, dan anak. Jika terjadi pertengkaran maka yang didahulukan adalah hak atau kepentingan si anak. Yang dimaksud hadhânah di sini adalah kewajiban orang tua untuk memelihara dan mendidik anak mereka dengan sebaik-baiknya. Pemeliharaan ini dapat mencakup masalah ekonomi, sandang pangan, pendidikan, dan suatu yang menjadi kebutuhan pokok si anak. ${ }^{32}$

Para fuqaha mendefinisikan hadhânah yaitu melakukan pemeliharaan anak-anak yang masih kecil, baik laki-laki maupun perempuan, atau yang sudah besar tetapi belum mumayyiz, menyediakan sesuatu yang menjadikan kebaikannya, menjaganya dari sesuatu yang menyakiti dan merusaknya, mendidik jasmani, rohani dan akalnya, agar mampu berdiri sendiri menghadapi hidup dan menutur tanggung jawab. ${ }^{33}$ Hadhânah berbeda maksudnya dengan pendidikan anak (tarbiyatul aulâd). Dalam hadhânah terkandung pengertian pemeliharaan jasmani dan rohani secara umum yang mencakup pula pengertian pendidikan terhadap anak (tarbiyatul aulâd), tetapi tetapi pendidikan anak ini berada di bawah payung hadhânah. Pendidik mungkin terdiri dari keluarga si anak, dan mungkin bukan dari keluarga si anak, dan ia merupakan pekerjaan sosial, sedangkan hadhânah dilaksanakan dan dilakukan oleh keluarga si

\footnotetext{
32 Amiur Nuruddin dan Azhari Akmal Tarigan, Hukum Perdata..., hlm. 292-293. Dan Ahmad Rofiq, Hukum Islam di Indonesia, (Jakarta: Rajawali Press, 1998), hlm. 235-236. Lihat juga dalam Abdu Aziz Dahlan, Ensiklopedi Hukum Islam, (Jakarta: Ikhtiar Baru Van Hoepe, 199), hlm. 415.

33 Amiur Nuruddin dan Azhari Akmal Tarigan, Hukum Perdata..., hlm. 293.
} 
anak, kecuali jika anak tidak mempunyai keluarga serta ia bukan professional, dilakukan oleh setiap ibu, serta anggota kerabat yang lain. ${ }^{34}$ Artinya, hadhânah merupakan hak dari hâdhin, sedangkan pendidikan belum tentu merupakan hak dari pendidik baik orang tua atau pihak yang dipercaya untuk membantu mengasuh dan mendidik anak.

Selain kewajiban orang tua memelihara, dan menjaganya dengan baik, di sini juga sangat krusial mengenai kewajiban orang tua terhadap pengarahan bagi pendidikan anak. Yang dimaksud dengan pendidikan anak (tarbiyatul aulâd) adalah kewajiban orang tua untuk memberikan pendidikan dan pengajaran yang memungkinkan anak tersebut menjadi manusia yang mempunyai kemampuan dan kecakapan sesuai dengan bawaan bakat anak tersebut yang akan dikembangkan di tengah-tengah masyarakat. Meskipun cakupan hadhânah sangat kompleks yaitu dengan mengawasi, pelayanan, mencukupi semua kebutuhannya, pencukupan nafkah anak sampai anak tersebut mencapai batas umur yang sudah beranjak dewasa (baligh) dan mampu untuk berdiri sendiri. ${ }^{35}$

Hadhânah dalam fiqh tidak secara komprehensif membahas tentang pendidikan anak. Oleh karena itu, penulis memberi jabaran-jabaran hadhânah ini sesuai pendapat ulama klasik dan Imam madzhab di atas. Hadhânah yang berarti pemeliharaan dan pengasuhan anak termasuk dalam hal menyusui anak bagi seorang ibu adalah menjadi ciri khas dalam pembahasan fiqh konvensional ini. Akan tetapi, paling tidak kategori hadhânah dalam perspektif ini memberikan gambaran bahwa orang tua mempunyai peran dalam hal mengasuh dan membesarkan anak hingga dewasa. Dalam hal ini menurut hemat penulis juga merupakan bentuk pendidikan orang tua bagi anak. Pendidikan di sini bukan berarti hanya dalam bentuk pengajaran, melainkan pemeliharaan, membesarkan dari kandungan hingga lahir adalah merupakan proses pendidikan pertama yang dilakukan orang tua.

Sebagaimana yang disinggung dalam al-Qur'an, hadits Nabi, dan kitabkitab fiqh konvensional, UU No. 1 tahun 1974 juga mempunyai pasal khusus tentang hadhânah (mencakup pengasuhan dan pendidikan anak). Bahkan,

\footnotetext{
34 Ibid.

35 Ibid., hlm. 294.
} 
dalam kitab UU No. 1 Tahun 1974 ini juga membahas mengenai perlindungan anak (hadhânah) ketika terjadi putusnya perkawinanan karena perceraian. Siapakah yang berhak dan bahkan wajib memelihara dan mendidik ketika terjadi perselisihan antara suami dan isteri. Sebagaimana dalam pasal 41 ayat 1 dikatakan bahwa "Baik ibu atau bapak tetap berkewajiban memelihara dan mendidik anaknya, semata-mata berdasarkan kepentingan anak, bilamana ada perselisihan mengenai penguasaan anak Pengadilan memberikan keputusannya. ${ }^{36}$

Dari keterangan ini cukup jelas bahwa hadhânah mempunyai batasanbatasan tertentu. Akan tetap, berbeda dengan Undang-undang di negara Muslim seperti di Mesir (No. 25 tahun 1929 pasal 20) dengan menganut Madzhab Hanafi yang menyatakan bahwa berakhirnya masa mengasuh dan mendidik anak (hadhânah) apabila si anak sudah berusia 7 tahun bagi lakilaki dan 9 tahun bagi anak perempuan. Di Sudan memakai Madzhab Maliki. Hakim di Sudan diberi wewenang untuk menetapkan seorang perempuan mengasuh anak laki-laki dari usia 7 tahun menjadi sampai baligh, dan batas anak perempuan adalah 9 tahun atau sampai kawin dan dicampuri oleh suaminya. ${ }^{37}$

Kalau terjadi perceraian antara suami dan isteri, dalam Kompilasi Hukum Islam mengatur tentang kedudukan anak seperti yang tertulis dalam pasal 105 dan 106. Pada pasal 105 misalnya pada poin a. Pemeliharaan anak yang belum mumayyiz atau belum berumur 12 (dua belas) tahun adalah hak ibunya. $b$. Pemeliharaan anak yang sudah mumayyiz diserahkan kepada anak untuk memilih di antara ayah atau ibunya sebagai pemegang hak pemeliharaannya. c. Biaya pemeliharaan ditanggung oleh ayah. ${ }^{38}$ Termasuk menyangkut harta yang dimiliki anak diatur dalam pasal 106, tetapi tidak menjadi pembahasan dalam tema ini. Pada initinya pasal-pasal KHI yang mengatur tentang hadhânah (pengasuhan, pemeliharaan, dan pendidikan anak) ini menegaskan bahwa kewajiban pengasuhan material dan non material merupakan dua hal yang tidak dapat dipisahkan. Bahkan KHI pun sangat proporsional dalam mengatur tugas-tugas yang harus diemban oleh kedua orang tua, meskpin

\footnotetext{
36 Ibid.

37 HLM.S.A. Hamdani, Risalah Nikablm..., hlm. 318-323.

38 Amiur Nuruddin dan Azhari Akmal Tarigan, Hukum Perdata..., hlm. 302.
} 
sudah bercerai. Anak yang belum mumayyiz (belum berumur 12 tahun) tetap diasuh oleh ibunya, sedangkan pembiayaan menjadi tanggungjawab ayahnya. Kalau anak sudah mumayyiz diberi hak untuk memilih ikut ayah atau ibunya. Dalam hal pendidikan anak tentunya menjadi kewajiaban orang tua, baik dalam kondisi bercerai ataupun tidak, hingga ia dewasa.

Begitulah Islam, perhatiannya sangat besar dalam kemaslahatan perkembangan kepribadian anak hingga dewasa. Sebab kepribadian Muslim yang kuat baik dalam keimanan, kejiwaan, pendidikan maupun akhlaq adalah modal utama anak itu untuk hidup dan berhasil dunia akhirat Hak anak dalam Islam dirinci al-Qur'an dan hadits-hadits Nabi Saw, fiqh konvensional, Undang-undang Perkawinan, hingga Kompilasi Hukum Islam yang mengatur tentang hadhânah yang di dalamnya mencakup perlindungan, pengasuhan, pemeliharaan, dan pendidikan anak. Masa depan pendidikan anak kemudian akan terarah pada pengembangan potensi dan sumber daya manusia secara seimbang dan optimal. Dengan kemampuan mengaktualisasikan potensi ini berarti pendidikan anak (tarbiyatul aulâd) telah mampu merealisasikan diri, yakni bersikap sebagai pribadi yang utuh sesuai dengan prinsip dan nilai-nilai universal dalam hukum Islam. ${ }^{39}$

Perlu digaris bawahi bahwa hak-hak hadhânah tentang pendidikan anak adalah menjadi kewajiban bagi orang tua. Bagi seorang ayah lebih pada pemenuhan materil dan juga immateril. Sedangkan ibu, lebih mencakup pada kebutuhan immateril seperti menyusui, membesarkan, mendidik, mengasuh hingga dewas, dan seterusnya karena secara psikologis kedekatan anak dengan seorang ibu dapat mempengaruhi bagi perkembangan pendidikan anak. Meskipun seorang ayah juga terlibat dalam pemenuhan kebutukan materil bagi anak. Menurut hemat penulis, perlu digaris bawahi bahwa hak-hak anak dalam hadhânah ia berhak mendapatkan pengasuhan, mendapatkan hak kebutuhan materil dan immateril, hak mendapatkan pendidikan yang layak, dan ketika oang tua becerai, seorang anak mempunyai hak unutk memilih ikut seorang ayah atau seorang ibu sebagaimana yang sudah diatur dalam UU No. 1 Tahun 1974 dan kemudian dilengkapi dalam KHI Indonesia.

39 Ahmad Tafsir, Ilmu Pendidikan dalam Perspektif Islam, (Bandung: Remaja Rosdakarya, 1992), hlm. 32, dan Ahmad D. Marimba, Pengantar Filsafat Pendidikan Islam, (Bandung: A-Ma’arif, 1989), hlm. 19 


\section{E. Kespmpulan}

Di era globalisasi ini hadhânah tentang pendidikan anak (tarbiyatul aulâd) yang menjadi kewajiban orang tua akan berdampak terhadap persoalan nilai moral, sosial budaya dan keagamaan yang semakin berkembang dan kompleks seperti di Indonesia. Sudah saatnya perhatian para akademisi, guru, dosen, dan orang tua terhadap perkembangan pendidikan bagi anak sangat dibutuhkan, karena anak adalah aset bangsa, sehingga apabila para generasi semakin luas ilmu pengetahuannya, maka akan semakin maju negaranya termasuk Indonesia ke depan perlu memperhatikan lebih serius mengenai pendidikan anak dan hak-haknya dalam mengenyam pendidikan yang lebih layak demi masa depan anak yang lebih baik.

Secara ringkas dalam Artikel ini berbicara mengenai arti nilai filosofis dari hadhânah tentang pendidikan anak mempunyai implikasi besar terhadap keluarga. Semua terangkum dalam Al-Qur'an QS. Luqman ayat 12-19, hadits Nabi, fiqh konvensional seperti pendapat para fuqaha (Imam Hanafi, Imam Hambali, hingga Wahbah Az-Zuhaily) yang mengatakan bahwa hadhânah (pendidikan anak) merupakan kewajiban kedua orang tua hingga dewasa. Undang-undang Perkawinan No. 1 Tahun 1974 juga mengatur tentang hadhânah (pendidikan anak) yang sesuai dengan prinsip-prinsip maqashid alsyariah dalam Islam.

\section{DAFTAR PUSTAKA}

A.Qodri Azizi, Eklektisisme Hukum Nasional: Kompetisi Antara Hukum Islam dan Hukum Umum, (Yogyakarta: Gama Media, 2002).

Abdu Aziz Dahlan, Ensiklopedi Hukum Islam, (Jakarta: Ikhtiar Baru Van Hoepe, 199).

Ahmad D. Marimba, Pengantar Filsafat Pendidikan Islam, (Bandung: A-Ma'arif, 1989).

Ahmad Fu'ad Al-Ahwani, At-Tarbiyah fî al-Islâm, (Mesir: Dar al-Ma'arif, t.t.). Ahmad Tafsir, Ilmu Pendidikan dalam Perspektif Islam, (Bandung: Remaja Rosdakarya, 1992).

Ali Ahmad al-jarjani, Hikmatu at-Tasyrî' Wa Falsafatuhîu, (Libanon: Dâr alFikr, t.t.). 
Amir Mua'allim dan Yusdani, Konfigurasi Pemikiran Hukum Islam, (Yogyakarta: UII Press, 1999).

Amiur Nuruddin dan Azhari Akmal Tarigan, Hukum Perdata..., hlm. 292293. Dan Ahmad Rofiq, Hukum Islam di Indonesia, (Jakarta: Rajawali Press, 1998).

F. Ivan Nye et.all; Role Structure and Analysis of the Family, Published in Coopration With The National Council On Family Relations, (London: Sage Library of Social Research, 1976).

Fathurrahman Djamil, Filsafat Hukum Islam, (Jakarta: Logos Wacana Ilmu, Cet. Ke-3, 1999).

Hans Wehr, A Dictionay of Modern Written Arabic, (Beirut: Librairie du Liban, Cet. Ke-4, 1974).

Hidayatullah Ahmad, Ensiklopedi Pendidikan Anak Muslim, terj. Sari Narulita dan Umron Jayadi, (Jakarta: Fikr Rabbani Grop, 2006).

HLM.S.A. Hamdani, Risalah Nikah, (Hukum Perkawinan Islam), terj. Agus Salim, (Jakarta: Pustaka Amani, 2002).

Imam Syaukani, Rekonstruksi Epistemologi Hukum Islam Indonesia dan Relevansinya Bagi Pengembangan Hukum Nasional, (Yogyakarta: Rajawali Press, 2006).

Imam al-Ghazzali, Ihyâ' 'Ulûmuddîn, (Beirut: Dar al-Fikr, 1939).

Imam Suprayogo, Pendidikan Berparadigma Al-Qur'an, (Malang: Aditya Media, t.t.).

Muhammad Munir Mursi, At-Tarbiyah Al-Islâmiyyah: Ushûluhâ Tathawwuruhâ fì al-Bilâd al-Arabiyah, (Mesir, Dar Al-Ma’arif, 1987).

Munir Muhammad al-Ghadhban, Menyiapkan Anak Perempuan Shalehah Untuk Pemuda Muslimah, Terj. Saiful hadi, (Jakarta: Mustaqim, Cet. Ke-2, 2003).

Musa Asy'arie, "Filsafat Islam Suatu Tinjauan Ontologis", dalam Amin Abdullah dkk., Irma Fatimah (ed)., Filsafat Islam kajian Ontologis, Epistemologis, Aksiologis, Historis, dan Perspektif, (Yogyakarta: LESFI, 1992).

Suryosubrata B., Beberapa Aspek Dasar Kependidikan, (Jakarta: Bina Aksara, 1983).

Yudian Wahyudi, Maqashid Syariah dalam Pergulatan Politik Berfilsafat Hukum Islam dari Harvard ke Sunan Kalijaga, (Yogyakarta: Nawesea Press, 2007). 